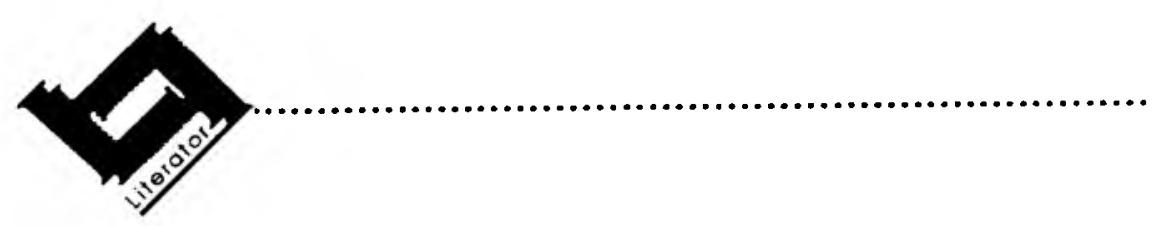

\title{
Dawie Steenberg - literator en mens
}

Hierdie nommer van Literator word opgedra aan Dawie Steenberg as blyk van waardering vir (a) sy betekenisvolle bydrae tot navorsing oor die Afrikaanse letterkunde, by name die Afrikaanse prosa en (b) vir die besondere rol wat hy gespeel het by die totstandkoming en instandhouding van Literator.

Dawie het aan die einde van 1997 met pensioen afgetree na 'n akademiese dienstermyn van byna 30 jaar aan die PU vir $\mathrm{CHO}$. Hy was voor dié tyd, na sy studie aan die PU, onderwyser.

Sy loopbaan is gekenmerk deur gewilligheid tot diensbaarheid: diensbaarheid aan die PU, diensbaarheid aan sy vak en bowenal ook diensbaarheid aan sy kerk waar hy jarelank in die kerkraad gedien het en 'n verskeidenheid ampte beklee het.

Dwarsdeur sy wetenskaplike oeuvre loop die goue draad van lewensbeskoulikheid: hy bekyk die Sestigers en skryf (in 1975) aan die hand van hulle werk 'n inleiding tot 'n Christelike literatuurbeskouing en kritiek. 'n Verskeidenheid dergelike publikasies het hierop gevolg: in 1981 'n publikasie oor lewensbeskouing en literatuurbeskouing; in 1984 skryf hy 'n vergelykende artikel oor Bybelteks en romanteks na aanleiding van Houd-den-Bek van André P. Brink. 'n Hoogtepunt in hierdie opsig is die omvattende ondersoek wat hy met 'n groter RGN-toekenning onderneem het oor die voorkoms van die Christelike gegewe in die Afrikaanse letterkunde en waaruit ook etlike publikasies gespruit het.

Met hierdie publikasies was Dawie getrou aan die roeping en ingesteldheid waartoe die PU vir CHO hom verbind, naamlik onderrig en navorsing "in U lig".

Die lewensbeskoulike aard van sy navorsing skemer steeds in sy werk deur - ook wanneer hy na die modernistiese stromings in die letterkunde kyk.

Die M.- en D.-studente wat onder hom afgestudeer het, was altyd bewus van Dawie as literator, maar ook as diepgelowige mens wat nooit skaam was om sy standpunt ook in hierdie verband te stel nie.

My persoonlike belewing van Dawie Steenberg het veral betrekking op sy deursettingsvermoë en onverskrokkenheid. Lewensleed is hom nie gespaar nie: Elbie, 
sy eggenote, se ernstige siekte vir meer as 20 jaar van hulle huwelikslewe, moes hom diep geraak het.

Ondanks die swaarkry was hy 'n vasbyter. Ek het hom nooit hoor kla nie. Veral as leier van twee groot RGN-navorsingsprojekte oor die Christelike gegewe in die Afrikaanse letterkunde (1985) en die Simbolisme in die Afrikaanse letterkundige tradisie (1992), het hy 'n navolgenswaardige voorbeeld gestel. As sy span, waarvan ek deel was, al moedeloos was, het Dawie voortgebeur, aangemoedig en gesorg dat daar geproduseer word: twee lywige publikasies van onderskeidelik 1139 en 695 bladsye elk het onder sy leiding tot stand gekom.

Dawie het op verskeie vlakke deelgeneem aan die bestuur van die PU: verskeie kere as waarnemende departementshoof, as lid (vir etlike jare) van die Fakulteit Lettere en Wysbegeerte se Dagbestuur, lid van die Fakulteit se Komitee vir Teoretiese Vorming e.s.m. Hy het ook sy gewig ingegooi by die Departement Filosofie en jarelank die lewensbeskoulike aspekte van literatuur binne die raamwerk van Filosofie gedoseer. Hy was ook jarelank die Fakulteit se verteenwoordiger in die Senaatskomitee vir Reformatoriese Wysbegeerte.

Buite die PU het hy sy bydrae gelewer tot die georganiseerde studie van die Afrikaanse letterkunde deur sy betrokkenheid (lank as bestuurslid) by die Afrikaanse Letterkundevereniging (ALV), die SA Vereniging vir Literatuurwetenskap (SAVAL) asook die SA Akademie vir Wetenskap en Kuns. By laasgenoemde instelling het hy as lid van die Letterkundekommissie, onder andere vir die toekenning van die gesogte Hertzogprys vir Afrikaanse letterkunde, meegehelp aan die vorming en omraming van 'n kanon van die Afrikaanse letterkunde.

Hierdie spesiale nommer van Literator is 'n klein eerbetoon vir die groot werk wat deur Dawie Steenberg verrig is. Sy oud-kollegas en ook sy studente wil hiermee 'n man vereer wat binne die studie van die Afrikaanse letterkunde 'n huishoudelike naam geword het. Mag daar in die uitspandae (langs die see by Pringlebaai en sy geliefde Clarens) nog baie produkte uit sy pen vloei

\section{Jacques van der Elst}

Dekaan: Lettere en Wysbegeerte

$\mathrm{PU}$ vir $\mathrm{CHO}$ 